\title{
THE EFFECT OF HEURISTIC STRATEGIES AND CRITICAL THINKING ABILITY ON STUDENT LEARNING OUTCOMES OF THE VALUES OF PANCASILA ON PPKN SUBJECTS CLASS VI SD SWASTA HKBP 2 SIDORAME, MEDAN
}

\author{
Santy Manalu 1 \\ State University of Medan, Indonesia \\ E-mail : santymanalu81@gmail.com \\ Deny Setiawan ${ }^{2}$ \\ State University of Medan, Indonesia \\ Daulat Saragi ${ }^{3}$ \\ State University of Medan, Indonesia
}

\begin{abstract}
This study aims to determine: 1) The influence of heuristic learning strategies and expository learning strategies on student learning outcomes, 2) The influence of critical thinking skills on student learning outcomes. 3) The interaction between heuristic learning strategies and critical thinking skills on student learning outcomes. This study used a quasi-experimental research method. The research was conducted from April to May 2021.The population of this study were students of class VI SDS HKBP 2 SIDORAME Medan with a total of 50 students. The sample is the VIA class with 26 students as the experimental class and the VIB class with 24 students as the control class. The data collection technique used a critical thinking ability questionnaire and a learning outcome test. The data analysis technique used two-way analysis of variance. The results of the study are as follows: (1) There are differences in learning outcomes students who were taught with heuristic learning strategies with an average value of 86.15 higher than the learning outcomes of students taught with expository learning strategies with an average of 76.39, the results of the analysis of variance showed that the $F_{\text {count }}$ value was 3,795> the $F_{\text {table }}$ value was 3.19 and the probability value or significance of $0.08<0.05$, so that $\mathrm{HO}$ is rejected; (2) There is a significant difference between student learning outcomes with high critical
\end{abstract}


thinking skills and the average88,409and students who have low critical thinking skills on average 68,133. Result of analysis of variance obtained $F_{\text {count }}$ value of

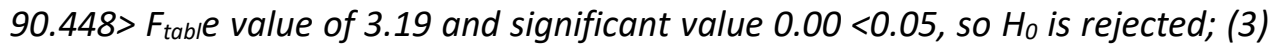
There is an interaction between heuristic learning strategies and students critical thinking abilities in improving student PPKn learning outcomes, the results of analysis of variance $F_{\text {count }}$ value of $4.134>F_{\text {table }}$ value of 3.19 and a significance of $0.006<0.05$, so $H_{0}$ is rejected.

Keywords: heuristic learning strategies, critical thinking skills, PPKn learning outcomes

\section{A. Introduction}

The "Covid-19 pandemic" that hit almost all countries in the world. COVID-19. Disasters that hit almost all countries in the world have made every country implement a "Lockdown" policy, which means that no citizen can do activities outside the home. All activities, both work and school, must be carried out from home.

Each school runs fully online teaching and learning activities. Online learning is learning that is done online, using learning applications and social networks. Online learning is learning that is done without face to face, but through available platforms such as WhatsApp, Google Classroom, Zoom, Google Meet, Youtube, etc. This makes the challenge of teachers increasingly difficult to carry out their duties in order to achieve the expected educational goals, especially for teachers who are not familiar with technology. Teachers are required to provide learning using learning media that have not even been mastered by the teacher himself.

Various new problems arise during the implementation of online learning. Especially for students who live in remote villages who have poor internet connection coverage, lack of funds to buy internet packages, loss of concentration in studying at home, boredom, students feel bored, too many assignments make students stressed in learning plus [560] 
a lack of good cooperation. both between teachers and parents and the reduced application of Pancasila values, this makes student learning outcomes decrease.

Although the government has made various efforts to overcome various obstacles that occur, such as schools are given flexibility in choosing and implementing the appropriate curriculum, free package assistance and online learning programs from TV. However, the reality is that in schools, especially SDS HKBP 2 SIDORAME Medan, there are still obstacles in learning outcomes in students critical thinking skills, this is influenced by the limited space and interaction between students and students and teachers.

Limited space and interaction make students less active in conveying ideas or opinions during learning which is one of the benchmarks for teachers in evaluating students thinking abilities. This certainly affects student learning outcomes which are decreasing. In addition to the obstacles above, there are various new obstacles in the implementation of online learning, including; 1 ) students do not like online learning because students feel bored, bored and students lose the freedom to socialize with friends, 2) students lose motivation to learn because of monotonous learning conditions, 3) students feel stressed because of too many assignments, 4) students cannot follow online learning due to the lack of internet packages, 5) learning is often interrupted due to poor or even no internet network, 6) teachers are not creative in delivering learning because the learning strategies used are still expository, 7) teachers cannot manage the class optimally because of limited space so that the class is not conducive, 8) learning cannot be maximized because various reasons arise from students not attending class. online learning as well as when collecting assignments, 9) online 
learning becomes a new burden for parents because the needs of students in online learning are greater such as having to provide smartphones and internet packages and 11) the lack of cooperation between parents and teachers is an obstacle for teachers in monitoring assignments and student progress in learning. These constraints certainly have an influence on student learning outcomes.

Based on the results of observations and interviews conducted at SDS HKBP 2 SIDORAME Medan with school principals and sixth grade teachers, it shows that student learning outcomes have decreased. Teachers of course have to change the strategy used previously, namely expository and look for new strategies that can be used to create an attractive and student-centered learning space so that it can have an impact on the progress of critical thinking skills, students are willing to study seriously, focused, enthusiastic, cheerful. , active, skilled, critical, disciplined and conducive when learning takes place. There are various learning strategies that can be used by teachers such as discovery learning strategies (discovering learning), inquiry learning strategies (learning investigations), problem based learning strategies (problem-based learning), project based learning strategies (project-based learning) scientific learning strategies (scientific learning) and heuristic strategies. Each strategy has different steps, each have advantages and disadvantages. Teachers can choose which strategies can be applied and are expected to have a good influence on student progress in learning in order to achieve the expected learning objectives. With various considerations the chosen strategy is to apply heuristic learning strategies.

Based on the phenomenon of the problem, researchers are interested in seeking the development of a heuristic strategy through [562] 
active, creative, innovative and interesting learning strategies so that later it is expected to improve student learning outcomes in the material of Pancasila values in Civics subjects with the title research "The Influence of Heuristic Strategy on Critical Thinking Ability and Student Learning Outcomes of Pancasila Values in Civics Subject Class VI Private Elementary School HKBP 2 SIDORAME Medan".

\section{B. Method}

\section{Research Location and Time}

The location of the research was carried out at the HKBP 2 SIDORAME Private Elementary School, Medan in class VI with the address at Jalan Dorowati No. 40 Medan. The time of the research was carried out in the second semester of the 2020/2021 Academic Year.

\section{Research Population}

The population in this study were all students of class VI SDS HKBP 2 SIDORAME Medan which consisted of 2 parallel classes totaling 50 students with the number of each class being class VI-A totaling 26 students and class VI-B totaling 24 students.

\section{Research Sample}

The sample in this study was the entire population, namely 50 students consisting of 26 students in class $\mathrm{VI}-\mathrm{A}$ and 24 students in class VIB. The total sample size is 50 students.

\section{Treatment Control}

Internal Validity

Control of internal validity is intended so that the results obtained are really the result of the treatment given to each experimental group. Internal validity controls include:

1. The historical effect 
2. Effect of maturity (maturation effect),

3. The influence of the instrument (instruent effect),

4. The effect of subject differences (differential selection of subject effect),

5. The effect of losing experimental participants (mortality effect),

6. Effect of contamination between experimental classes (selection maturation interaction effect).

External Validity

External validity control is carried out with the aim that the research results can be generalized to the research population. External validity includes:

1. Population validity

2. Ecological validity

\section{Finding and Discussion}

\section{Results}

The research that has been carried out is a quasi-experimental study to see the effect of heuristic learning strategies on students critical thinking skills and student Civics learning outcomes and the effect of expository learning strategies on students critical thinking skills and Civics learning outcomes in grade VI. This research was conducted in a school, namely the HKBP 2 SIDORAME Private Elementary School Medan. Next, a random draw was made to determine the experimental class and the control class. The lottery results show class VI-A as the experimental class and class VI-B as the control class. Data collected from the results of further research,

Based on the research analysis design, the frequency distribution of the data presented are: (1) pree test of Civics learning outcomes of [564] 
experimental class students; (2) pree test of Civics learning outcomes of control class students; (3) a description of the students critical thinking skills in the experimental class; (4) a description of the critical thinking skills of control class students; (5) post test of Civics learning outcomes of Heuristics class students; (6) post-test of expository class PPKn learning outcomes for students; (7) Civics learning outcomes of students who have high critical thinking skills; (8) the learning outcomes of students who have low critical thinking skills; (9) Civics learning outcomes of students who are taught by applying heuristic learning strategies and have high critical thinking skills; (10) Civics learning outcomes of students who are taught by applying heuristic learning strategies and have low critical thinking skills of students; (11) Civics learning outcomes of students who are taught by applying expository learning strategies and have high critical thinking skills of students and (12) Civics learning outcomes of students who are taught by applying expository learning strategies and have low critical thinking skills of students.

\section{Description of Research Result Data}

1. Pree Test of Civics Learning Outcomes for Experimental Class Students

The value of the PPKn learning outcomes of experimental class students with the highest number of frequencies is in the interval class with a value of 67-71 with a total of 9 students or a percentage of $35 \%$, while the number of frequencies with the lowest number is in the interval class with a value of 62-66 with a total of 0 students or a percentage of $0 \%$.

2. Pree Test of Civics Learning Outcomes for Control Class Students

PPKn learning outcomes scores of control class students with the highest number of frequencies are in the interval class with a value of 6771 with a total of 7 students or a percentage of $29 \%$, while the lowest 
number of frequencies is in the interval class with a value of 62-66 with a total of 0 students or a percentage of $0 \%$.

3. Description of Experimental Class Students Critical Thinking Ability

The value of critical thinking ability of experimental class students with the highest number of frequencies in the class interval grades 62-66 with a total of 7 students or a percentage of $27 \%$, while the number of frequencies with the least number is in the interval class 47-31 and the interval class $72-76$ with a total 3 students or a percentage of $12 \%$.

4. Description of Control Class Students Critical Thinking Ability

The learning motivation value of control class students with the highest number of frequencies is in the interval class with a value of 62-66 and an interval class with a value of 67-71 with a total of 7 students or a percentage of $27 \%$, while the lowest number of frequencies is in the interval class with a value of $52-56$ with a total of 0 students or $0 \%$ percentage.

5. Post Test of Civics Learning Outcomes of Students who are Taught Heuristic Learning Strategies

The value of student learning motivation in the class taught by applying the Heuristic learning strategy the highest number of frequencies is in the interval class grades 91-96 with a total of 9 students or a percentage of $35 \%$, while the least frequency is in the interval class grades 67-72 with a total of 2 students or a percentage of $8 \%$.

6. Post Test of Civics Learning Outcomes of Students who are Taught Expository Learning Strategies

The value of Civics learning outcomes of class students who are taught by applying expository learning strategies the highest number of frequencies is in the interval class grades 79-84 with a total of 7 students or a percentage of $27 \%$, while the lowest number of frequencies is in the [566] 
interval class grades $67-72$ and the interval class the value of 97-102 with the number of 2 students or a percentage of $8 \%$.

\section{Civics Learning Outcomes of Students Who Have High Critical Thinking Ability}

The value of high learning motivation of students with the highest frequency is in the class interval grades $72-73$ with a total of 12 students or a percentage of $57 \%$, while the number of frequencies with the lowest number is in the interval class grades $78-79$ with a total of 0 students or a percentage of $0 \%$.

\section{Civics Learning Outcomes of Students Who Have Low Critical Thinking Ability}

The value of high learning motivation of students with the highest frequency is in the class interval grades $72-73$ with a total of 12 students or a percentage of $57 \%$, while the number of frequencies with the lowest number is in the interval class grades $78-79$ with a total of 0 students or a percentage of $0 \%$.

\section{PPKN Learning Outcomes Taught With Heuristic Learning Strategies and Have High Critical Thinking Ability}

The value of Civics learning outcomes of students who are taught with heuristic learning strategies and have high critical thinking skills class students who are taught by applying heuristic learning strategies the highest number of frequencies is in the class interval value of 79-82 with a total of 12 students or a percentage of $32 \%$, while the total frequency at least are in the 75-78 grade interval with a total of 1 student or a percentage of $3 \%$. 
10. PPKN Learning Outcomes Taught With Heuristic Learning Strategies and Have Low Critical Thinking Ability

The value of Civics learning outcomes for students who are taught using a heuristic learning strategy model and have low critical thinking skills, the highest number of frequencies is in the 69-70 grade interval class with a total of 3 students or a percentage of $50 \%$, while the least number of frequencies is in the grade interval class. 63-64 with 1 student or a percentage of $17 \%$.

\section{PPKN Learning Outcomes Taught With Expository Learning Strategies and Have High Critical Thinking Ability}

The value of Civics learning outcomes of students who are taught with expository learning strategies and have high critical thinking skills of class students who are taught by applying expository learning strategies the highest number of frequencies are in the class interval value of 84-87 with a total of 6 students or a percentage of 30\%, while the number of frequencies that at least are in the 88-91 grade interval class with a total of 0 students or a percentage of $0 \%$.

\section{PPKN Learning Outcomes Taught With Expository Learning Strategies} and Have Low Critical Thinking Ability

The value of Civics learning outcomes of students who are taught with the Expository learning model and have low critical thinking skills. The class students who are taught by applying the expository learning strategy have the highest number of frequencies in the class interval value of 67-68 with a total of 3 students or a percentage of $50 \%$, while the number of frequencies used is 67-68. at least are in the 65-66 grade interval class with a total of 0 students or a percentage of $0 \%$. 


\section{Discussion}

Civics Learning Outcomes of Students Taught With Heuristic Learning Strategies are Higher Than Students Taught With Expository Strategies

Heuristic learning can be done individually, in groups or classically. However, heuristic learning is better done in small groups so that there is discussion and exchange of ideas between fellow students while being given tasks to solve problems, especially in the practice stage. Because the Heuristic strategy has so many steps, it is hoped that it can improve learning which in turn can improve students critical thinking skills in problem solving in learning. In contrast to the expository learning strategy, the implementation using the expository learning strategy lies in emphasizing the process of delivering material verbally from a teacher to a group of students with the intention that students can master the subject matter in accordance with the predetermined objectives.

Expository learning learning is still teacher-centered, while students are directed to listen, write, summarize and memorize, while students heuristic learning strategies are stimulated for learning strategies that can form students to be active, critical, trying to find out and find out for themselves the problems presented by the teacher by use previous knowledge and experience in solving problems. Based on the results of the research conducted, it was found that the average Civics learning outcomes of students taught with heuristic learning strategies was 86.15 , meanwhile, the average Civics learning outcomes taught with expository learning strategies was 76.19.

Civics Learning Outcomes of Students who Have Higher Critical Thinking Ability are Higher than Students who have Low Critical Thinking Ability

The ability to think is one of the assets that students must have as a provision in facing the development of science and technology at this 
time. Critical thinking involves inductive thinking skills such as recognizing relationships, analyzing open-ended problems (with many possible solutions), determining cause and effect, making conclusions and calculating relevant data. The characteristics of someone who has the ability to think critically, which is able to solve a problem with a specific purpose, is able to analyze and generalize ideas based on existing facts, and is able to draw conclusions and solve problems systematically with the right arguments. If a person is only able to solve problems without knowing the reason for the concept being applied, then he cannot be said to have critical thinking skills. Setyawati, (2013: 116).

Critical thinking can be trained by getting students to be active in class, such as asking questions, expressing opinions, and daring to convey ideas. To build critical thinking in students, there are indicators that can be used as guidelines for teachers in teaching and learning activities. Critical thinking indicators that can be used by teachers are to pay attention to the following things: Knowing the problem; (b) find ways that can be used to deal with these problems; (c) collect data and compile the necessary information; (d) recognize unstated assumptions and values; (e) understand and use language appropriately, clearly and specifically; analyze data; (f) assessing facts and evaluating statements; (g) recognize the existence of a logical relationship between problems; (h) draw the necessary conclusions and similarities; (i) examine the similarities and conclusions one draws; (j) rearranging one's belief patterns based on broader experience; and (k) make proper judgments about things with certain qualities in everyday life.

Based on the results of the analysis of research data through the two-way ANOVA test, it was obtained that the average student learning outcome with a high level of critical thinking ability was 88.41 while the [570] 
average student learning outcome with a low critical thinking ability was 68.13. This proves that students critical thinking skills can affect student learning outcomes with the assumption that the higher students learning motivation, the higher the learning outcomes obtained by students.

\section{Interaction Between Heuristic Learning Strategies and Critical Thinking} Skills on Students Civic Education Learning Outcomes

Heuristic learning strategies are considered to be able to assist students in developing or increasing the availability and mastery of students cognitive skills and processes. The strength of the discovery process comes from the effort to find, so students are taught how to learn, can generate motivation in students as a result of students efforts to find and find a problem/problem with their own efforts, providing opportunities for students to move forward according to their needs. ability, students direct their own way of learning so that students feel more involved and self-motivated to learn, can help strengthen students personalities by increasing self-confidence through the process of discovery and investigation, helps the development of students towards healthy skepticism to find the ultimate and absolute truth and this strategy is child-centered so that learning becomes student centered, no longer teacher centered. This can make students bring out their hidden potential.

The results of hypothesis testing using two-way ANOVA for the third hypothesis, namely the interaction between heuristic learning strategies and students critical thinking skills in influencing student learning outcomes $F_{\text {cosnt }}=4.134$ and significant at 0.006 with $=0.05$. Then it can be seen that the significant value is $0.006<0.05$. and the probability value or significant value of the learning model is $0.006<0.05$. It can be concluded that the hypothesis rejects $H_{o}$ and accepts $H_{a}$, which 
means that there is an interaction between heuristic learning strategies and critical thinking skills in influencing student Civics learning outcomes.

\section{Conclusion}

Based on the formulation, objectives, results and discussion of the research on the influence of discovery learning and social skills learning models on Civics learning outcomes for class VI SDS HKBP 2 SIDORAME Medan previously stated, it can be concluded as follows:

a. There is a higher influence on student learning outcomes who are taught using heuristic learning strategies than students who are taught using expository learning strategies. This can be seen from the ANOVA calculation using SPSS version 22 which obtained an Fcount of 3.80 which is greater than the value of $F$ table 3.19 at a significance level of 0.05 so that $\mathrm{HO}$ is rejected. Thus, it can be concluded that student learning outcomes using heuristic learning strategies are higher than groups of students taught using expository learning strategies.

b. Based on the results of data calculations, it can be seen that the Civics learning outcomes of students who have high critical thinking skills are compared to the Civics learning outcomes of students who have low critical thinking abilities. This can be seen from the acquisition of Fcount $=90,448$ and sig.0,000 $<0.05$. Thus, it can be concluded that the group of students who have high critical thinking skills obtain higher learning outcomes than the group of students with low critical thinking skills that is proven true. There is an interaction between heuristic learning strategies and students critical thinking skills in influencing learning outcomes. This can be seen from the acquisition of Fcount $=4.134$ and sig. $0.006<0.05$. Thus, it can be concluded that 
there is an interaction between learning models that have high social skills on student learning outcomes that are proven to be true.

\section{Bibliography}

Abdul Majid. 2013. Strategi Pembelajaran. Bandung; PT Remaja Rosdakarya.

Adiyatno, F. Dkk. 2019. Penerapan Metode Heuristik Untuk Menentukan Jalur Distribusi Terpendek Dengan Biaya Minimum. Dalam jurnal Matematika dan Aplikasi. Vol.9, No.1. Hal.23-29.

Ariani, Dessy Noor. 2017. Pengaruh Pembelajaran Matematika Realistik Dengan Strategi Heuristik Krulik Dan Rudnik Terhadap Kemampuan Berfikir Kritis Dan Prestasi Belajar Siswa Sekolah Dasar. Madrasah Ibtidaiyah (Vol. 2, No. 2). Hal.12-22.

Aris Shoimin. 2014. 68 Model Pembelajaran Inovatif Dalam Kurikulum 2013. Yogyakarta: Ar-Ruzz Media.

Farida. 2016. Pengaruh Strategi Pembelajaran Heuristic Vee Terhadap Kemampuan Pemahaman Konsep Dan Komunikasi Matematis Peserta Didik Kelas VIII MTS Guppiibabatan Lampung Selatan Tahun Pelajaran. Vol 6. No.2. Hal.67-85.

Gurusinga dan Sibarani. 2011. Penerapan Strategi Pembelajaran Ekspositori Untuk Meningkatkan Hasil Belajar Siswa Fakultas Teknik Universitas Satya Negara Indonesia. Vol.2, No.4. Hal.29-31.

Harsanto, Radno. 2005. Melatih Anak Berpikir Analitik, Kritis dan Kreatif. Jakarta: Gramedia.

Nasution, Wahyudin Nur. 2017. Strategi Pembelajaran. Medan: Perdana Publishing.

Pramita, Dewi, dan Muh. Rusmayadi. 2018. Pengaruh Strategi Heuristik Pada Pendekatan Pemecahan Masalah Dalam Pembelajaran Matematika Kelas VIII SMP. Jurnal Teori dan Aplikasi Matematika. Vol. 2, No. 2, Hal. 157-161.

Sada, dkk. 2016. Prospects of Problem-Based Learning in Building Critical Thinking Skills among Technical College Students in Nigeria dalam Mediterranean Journal of Social Sciences MCSER Publishing, Rome-Italy. Vol.7. Nomor 3. Hal 105-115.

Sanjaya, Wina. 2011. Kurikulum dan Pembelajaran. Jakarta: Kencana Prenada Media Group. 
Setyawati, R.D. 2013. Pengembangan Perangkat Pembelajaran Matematika Model Problem Based Learning Berorientasi Enterpreneurship dan Berbantuan CD Interaktif. Prosiding Seminar Nasional Matematika 2013. Semarang: Universitas Negeri Semarang.

Sulistyarini. 2018. Model Inkuiri (Heuristic) Dalam Pembelajaran Pendidikan Kewarganegaraan (PKn). Jurnal Cakrawala Kependidikan Vol.6. No.2. September 2008. Hal.112-207.

Sutopo. 2018. Penerapan Model Pembelajaran Algoritma-Heuristik sebagai Upaya untuk Meningkatkan Kualitas Pembelajaran Praktik Pemesinan. Dalam jurnal pendidikan teknologi dan kejuruan. Vol.17, No.12. Hal.280-296. 